\title{
Effects of Immobilization Stress and Adrenomodullin on Interleukin-10 Levels in Some Rat Tissues
}

\author{
${ }^{1}$ Gadalla A., ${ }^{2}$ Al Gendy A, ${ }^{3}$ Hashim A.M., ${ }^{3}$ Amer M.M., ${ }^{4}$ Sabry \\ O.M.O.
}

${ }^{1}$ Department of Physiology, Faculty of Medicine, Al-Azhar University, Assuit, Egypt. ${ }^{2}$ Department of Physiology, Faculty of Medicine, Al-Azhar University, Cairo, Egypt.

${ }^{3}$ Department of clinical Pathology, Faculty of Medicine, Al-Azhar University, Assuit, Egypt, ${ }^{4}$ Department of haematology , Theodor Bilharze,Research institute, Cairo, Egypt

\begin{abstract}
Background: Immobilization stress known to stimulate sympathetic activity, as well as the hypothalamic-pituitary-adrenal axis (HPA), produces a significant increase in adrenomedullin (AdM) levels, suggesting a regulatory or protective role for AdM in countering HPA activation that follows a variety of stressors. Stressors can modulate the secretion of proinflammatory cytokines. Interleukin (IL)-10 is a potent activator of the HPA and appears to play a pathogenic role in conditions related to stress Objective: The aim of this study was to evaluate and validate the effects of AdM administration and immobilization stress treatment on IL-10 levels in rat liver, lung, brain and heart tissues. Materials and Methods: The study was carried out on twenty-four male albino rats (8 months old, 190-240 g). The animals were divided into 4 groups of 6 rats each group. Group A : control group. Group B : AdM-treated group , rats received intraperitonealy (i.p.) injection of AdM $(2000 \mu \mathrm{g} / \mathrm{g}$ body weight $)$ once daily for 1 week. Group C : immobilized stress group ,(rats were immobilized by keeping them into transparent plastic jars with 5 holes for 4 hrs per day for 1 week).Group D: immobilized stress +AdM group. Rats were immobilized by keeping them into transparent plastic jars with 5 holes for $4 \mathrm{hrs}$ a day for 1 week and were given AdM i.p at a single dose of $2000 \mu \mathrm{g} / \mathrm{g}$ body weight for a week. At the end of the experiment, the concentration of IL-10 was determined using an enzyme-linked immunosorbent assay (ELISA) kit. Results: The results of the present study showed that IL-10 levels increased in all tissues in immobilized stress group when compared to control, also IL-10 levels were increased in AdM treatment group in all tissues when compared to control . IL-10 levels were decreased in the immobilization stress + AdM treatment group in all tissues when compared to the stress group, increased IL-10 levels in brain and lung tissue but decreased in heart and liver tissues in the immobilization stress + AdM treatment group when compared to the AdM treatment group. Conclusion: The results suggest that immobilization stress may induce increase of rat proinflammatory cytokine IL-10 and AdM may play a regulatory or protective role for immobilization stress.
\end{abstract}

Key words: Immobilization stress; Adrenomedullin; Interleukin 10. 


\section{INTRODUCTION}

Stress has been defined as a state of disrupted homeostasis (1) .Stressors that challenge homeostasis can be divided into three general categories: physical e.g .restraint and exercise, psychosocial e.g. isolation, anxiety, fear, or mental frustration, and metabolic e.g. hypoglycemia and hemorrhage (2).Stress has been further classified according to duration into acute (single or intermittent exposure) and chronic (prolonged intermittent or continuous exposure). Immobilization stress can be considered a mixture of physical and psychological stressors, restricting movement and isolating the individual from its group (3) . During stress, an adaptive response originating in the hypothalamus-pituitary-adrenal (HPA) axis is activated to sustain homeostasis (4). This axis in particular has been considered the central mediator of the stress response (5). Inappropriate responses to stressors, such as inadequate, excessive, and or prolonged reactions, may turn deleterious and contribute to disease. In addition, chronically imposed or severe stressors can impair various physiologic functions (6). Psychological and physiological stressors in particular can disturb neuroendocrine, reproductive, and metabolic functions (7). Stress affects various aspects of immune function, depending on the nature and duration of the stress ( 8), (9). For example, stressors can directly affect the cells of the immune system and modulate the secretion of proinflammatory cytokines ( 10) .Cytokines are small secreted proteins released by cells have a specific effect on the interactions and communications between cells (11).Cytokine include lymphokine (cytokines made by lymphocytes), monokine (cytokines made by monocytes), chemokine (cytokines with chemotactic activities), and interleukin (cytokines made by one leukocyte and acting on other leukocytes).( 12),( 13). Cytokines are made by many cell populations, but the predominant producers are helper $\mathrm{T}$ cells (Th) and macrophages. (14). Major anti-inflammatory cytokines include interleukin (IL)-1 receptor antagonist, IL-4, IL-10, IL-11, and IL13. Among all the anti-inflammatory cytokines, IL-10 is a cytokine with potent anti-inflammatory properties ( 14).In addition, IL-10 can up-regulate endogenous anti-cytokines and downregulate pro-inflammatory cytokine receptors. Thus, it can counter-regulate production and function of proinflammatory cytokines at multiple levels. (15). Chronic stress is associated with dysregulation of the hypothalamic-pituitary-adrenal (HPA) axis, with consequent increase in the production of the hormone cortisol, and elevated levels of norepinephrine (NE) and epinephrine (E), which are catecholamines released from the adrenal medulla and the neurons of the sympathetic nervous system (SNS) as well as the HPA axis, produces a significant increase in adrenomedullin (AdM) levels in the pituitary gland, plasma and adrenal glands, all of which are the key components of the HPA axis . (16). AdM is implicated as a mediator of several pathologies, such as cardiovascular and renal disorders, 
sepsis, inflammation, diabetes and cancer, etc.( 17). AdM is expressed in a variety of tumours, where it aggravates several of the molecular and physiological features of malignant cells( 18). As stress is increasing in our life day by day. The aim of this study was to evaluate and validate the effects of AdM administration and immbolization stress on IL-10 levels in rat liver, lung, brain and heart tissues.

\section{Materials and Methods}

Adult male albino rats were chosen as an animal model for this study. Rats were brought from animal house, Faculty of Medicine, Assiut University, Assiut, Egypt, and were maintained on a balanced diet with free water supply in clean containers. They were kept for two weeks. Under this condition to adapt the laboratory conditions before the start of the experiment.. The study was carried out on twenty-four male albino rats (8 months old, 190-240 g). The animals were divided into 4 groups of 6 each.

Group A : Served as control group $(\mathrm{n}=$ 6) .

Group B : AdM -treated group $(n=6)$. The AdM-treated groups received an intraperitoneal (i.p.) injection of AdM (2000 $\mu \mathrm{g} / \mathrm{g}$ body weight)daily for 1 week. AdM was obtained from (Sigma Chemical Co., St Louis, MO, USA).

Group C : immobilized stress group $(n=6)$ (Rats of this group were immobilized by keeping them into transparent plastic jars with 5 holes for 4hrs. a day for 1 wek. These jars adjusted to fit the size of every rat.

Group D : immobilized stress +AdM group $(n=6)$. Rats of this group were immobilized by keeping them into transparent plastic jars with 5 holes for 4hrs daily for 1 wek and were given AdM i.p. at a single dose of $2000 \mu \mathrm{g} / \mathrm{g}$ body weight for a week, this was done $30 \mathrm{~min}$ before every exposure to immobilization stress.

At the end of the experiment, the rats were killed by i.p. injection of $\mathrm{Na}+$ thiopental $(120 \mathrm{mg} / \mathrm{kg})$ and the liver, lung, brain and heart were removed immediately. Liver, lung, brain and heart tissues were homogenized in icecold phosphate-buffered saline $(\mathrm{pH}$ 7.4). The homogenate was sonified with an ultrasonifier by six cycles. The homogenate was centrifuged (15 $00 \mathrm{~g}$ per min at $4^{\circ} \mathrm{C}$ for 10 minutes) and the supernatant was subjected immediately to enzyme assays. IL-10 levels was determined using ELISA mouse/rat interleukin 10 assay kits (Quantikine, R\&D Systems , Minneapolis, MN, USA) (Catalog. No. KRC00 81).

\section{Statistical analysis}

Statistical analysis of the difference between groups was done by One way analysis of variance (ANOVA) followed by Duncan's multiple range test for differences between means. The quantitative data were presented in the form of mean \pm standard error (S.E). A value of $\mathrm{P}<0.05$ were used as the limit for statistical significance.

\section{RESULTS}

The results clearly showed that IL-10 levels were significantly increased $(\mathrm{P}<0.05)$ in all tissues in immbolization stress group when compared to control $(\mathrm{P}<0.05)$ as shown in table 1. Also, IL-10 levels were increased in AdM treatment group in liver, brain and 
heart and lung tissue as shown in table 1, when compared to control ( $\mathrm{P}<$ 0.05).The increase in IL-10 were obvious and significant with the immbolization stress group $(\mathrm{P}<0.001)$ when compared to AdM treatment group in lung, brain and liver while the increase in IL-10 were obvious in heart in AdM treatment group $(\mathrm{P}<$ 0.001) when compared to the immbolization stress group. The results of this study showed that rats exposed to immobilization stress in addition to AdM administration associated with significant increase in IL-10 levels in brain, lung and heart tissue but decreased in liver tissues when compared to control rats but IL10 levels were decreased in the immobilization stress + adrenomedullin treatment group, in lung, heart tissues, liver and brain tissues when compared to the stress group $(\mathrm{P}<0.05)$ as shown in table 1 . The results of this study showed that rats exposed to immobilization stress in addition to AdM administration showed increased IL-10 levels in brain and lung tissue but decreased in heart and liver tissues when compared to the
AdM treatment group $(\mathrm{P}<0.05)$, as shown in table 1.

\section{DISCUSSION}

This study set out with the aim of assessing the effects of AdM administration on IL-10 levels in liver, lung, brain and heart tissues in response to immobilization stress in rats. All living organisms respond to stress changes in the environment in various ways. Activation of the stress system leads to behavioural and peripheral changes to improve the ability of the organism to adjust homeostasis and increase its chances for survival (19) .The physiological components of stress response are metabolic, circulatory and hormonal. (20). Different physiological stressors show a somewhat specific neuroendocrine response profile; the response of the pituitary-adrenal and sympatho-medullo-adrenal axes, however, are common to almost all stressors (21). Stress enhances the synthesis and release of catecholamines in the peripheral sympathetic system as well as in the brain, adrenal medulla and heart (22).

Tab . (1): Mean + SD of interleukin 10 in different tissue homogenate in different studied groups at end of experiment

\begin{tabular}{|c|c|c|c|c|}
\hline Groups & Liver & Lung & Brain & Heart \\
\hline Control & $170 \pm 3.7$ & $50 \pm 2.50$ & $30 \pm 2.70$ & $120 \pm 2.80$ \\
\hline Adm & $240 \pm 4.8 * *, \#$ & $55 \pm 3.40^{*}$ & $45 \pm 2.90^{*}, \#$ & $400 \pm 5.2 * * *$ \\
\hline $\begin{array}{c}\text { Immobilization } \\
\text { Stress }\end{array}$ & $360 \pm 5.6 * * *$ & $130 \pm 4.56 * * *$ & $60 \pm 3.70^{* * *}$ & $350 \pm 4.80 * * *$ \\
\hline $\begin{array}{c}\text { Immobilization } \\
\text { stress + Adm }\end{array}$ & $140 \pm 3.5 * * *$ & $60 \pm 3.80^{*}$ & $50 \pm 3.60^{*}, \#$ & $150 \pm 2.90 * *$ \\
$\# \# \#$ \\
\hline
\end{tabular}

The effect of immobilization stress and adrenomedullin treatment on interleukin-10 levels in rat tissues. * $\mathrm{P}<0.05$, ** $\mathrm{P}<0.01$, *** $\mathrm{P}<0.001$ compared to control; \# $\mathrm{P}<$ 0.05 compared to the stress (analysis of variance by One way analysis of variance (ANOVA) followed by Duncan's multiple range test, *\#P < 0.05). 
Stress-induced activation of the sympatho-adrenal medulla and the HPA axis, and this stimulates secretion of catecholamine (noradrenalin and adrenalin) and glucocorticoids, which are capable of modulating immune cells and further modulating cytokine production ( 23). Cytokines play a key role in bidirectional communication between the neuroendocrine and immune systems. The interplay between hormones and cytokines during immobilization stress may influence immune homeostasis in response to environmental challenges . Stress affects various aspects of immune function, depending on the nature and duration of the stress (24). The results of this study showed an increase in IL-10 levels in immobilization stress group in all tissues when compared to control .This findings of the current study are consistent with those of Rhind et al (25) who found that immobilization stress enhanced IL-10, IL-2 and tumour necrosis factor (TNF)- $\alpha$ cytokine levels in mice. Hangalapura $\mathrm{BN}$ et al (26) demonstrated that restraint stress induced elevation of the plasma IL-10 level in female albino rats. Nukina $\mathrm{H}$ et al (27) also reported that acute stress also causes elevation of serum IL-10 in rodents and precipitates myocardial infarction (MI) in atherosclerotic mice. Takaki et al (28) found that the possible explanations for this result that increase in plasma IL-10 would be produced from stress -related catecholamine secretion (central and peripheral). These results are in disagreement with the results obtained by Deliargyris EN et al (29) who reported that restrain stress has no effect on IL-10 cytokine levels. Results from the present study showed that the administration of AdM increases IL-10 levels in all tissues when compared to control. This finding is in agreement with findings of Yüksel et al (30) which showed that externally applied AdM produces an increase in IL-10 in isolated stressed rats. The results of this study showed that rats exposed to immobilization stress in addition to AdM administration showed increase in IL10 levels in brain, lung and heart tissue but decreased in liver tissues when compared to normal control rats. The increase in IL-10 were obvious and significant with the immbolization stress group $(\mathrm{P}<0.001)$ when compared to AdM treatment group in lung, brain and liver while the increase in IL-10 were obvious in heart in AdM treatment group $(\mathrm{P}<0.001)$ when compared to the immbolization stress group. This finding is in agreement with the results obtained by Yüksel et al (31) who reported that application of AdM in addition to restrain stress increases IL-10 levels in brain, lung and heart tissue but decreased in liver tissue of rabbits and this can be occurred via AdM receptors on different end-organs and causes altered metabolic regulation taking partial or total occupation of AdM receptors, stimulated in response to restrain stress application (Yüksel S, Akbay A and Yürekli M (32) . also Yüksel et al (33) studied whether light or dark stress is involved in the endogenous AdM production systems and showed that keeping the rats in a constant light/dark vicinity for a long time altered AdM synthesis and secretion from the plasma or other tissues. The 
differences in results between different tissues may be due to differences in tissues composition Isumi et al (34)found that AdM is a rapid and extraordinarily potent regulator of IL10 production and a peptidergic regulator of inflammation .Ueda et al (35) found increased plasma levels of AdM in patients with systemic inflammatory response syndrome. In the present study, results showed that AdM adminstration in immobilized stressed rats increased IL-10 levels in brain and lung tissue but decreased in heart and liver tissues when compared to the AdM treatment group . Although, these results differ from some published studies ( Averina T.M (36) they are consistent with those of (Hideyuki N, et al(37)who reported that administration of AdM increased IL-10 levels in brain and lung tissue but decreased in heart and liver tissues in isolation stressed rats. In the present study results showed that AdM decreased IL-10 levels in all tissues in immobilized stressed rats compared to the stress group . Hideyuki N, et al (38) suggested that administration of AdM was found to decrease IL-10 levels in all tissues in isolated stressed rats but induced decrease in IL-2 levels (Schoder $\mathrm{H}$ et $\mathrm{al}(39)$. In conclusion, One of the issues that emerges from these findings is that immobilization stress induced increase of IL-10 in rat liver, lung and brain and heart tissues. These results imply that stress may result in dysregulation of the Th1/Th2 cytokine profiles, break the Th1/Th2 balances and then affect immune response ( 40). It is known that, under stress conditions, the HPA axis is stimulated and catecholamine production is increased. (41). The results of our study suggest that AdM may play an important role in the continuity of homeostasis as antagonist substances to stress conditions. Sympathetic neuronal system and immune system are affected by AdM and cytokines after stress exposure. Future studies on the current topic are therefore recommended to understand the exact role of AdM in response to immobilization stress. The study of stress is a broad topic, and further research should be done to investigate further mechanism of regulation initially on the suggested rat model.

\section{References}

1-Gorizontov P.D., Belousova O.I., Fedotova M.I ( 1983):Stress and Blood System. M : Meditsina , 23 ,173 -198 .

2-Goldberg Ye. D., Khlusov I.S., Dygai A.M ( 2003): The adrenergic mechanisms controlling the proliferation and differentiation of Hematopoietic Precursor Cells under Immobilization Stress ,Biulleten' Eksperimental'noy Biologii I Meditsiny, 11, p. 457-460. 3-Averina T.M ( 2000) :Morphofunctional characteristics of the immune adaptive capacities of the lymphoid tissue of the spleen in a growing body immobilization stress. Morphology.V congress of IAM , v. $117, \quad 3, \quad$ p. 10 4-Zimin Yu.I (1979 ):Stress and Immunitet. VINITI , № 8, p. 173198.

5-Tseilikman V.E , Volchegorskii I.A., Kolesnikov O.A (1995):Formation of Tolerance of Rat Blood to the Re-action of the Stress Stimulus. Russ. Physiological Journal , v. 81, № 12,p. 88-94 . 
6-Pshennikova M.G. (2001): Stress Phenomenon. Emotional Stress and its Role in the Pathology. Ter. № 2, p. 26-30.

7-Dhabhar, F. $S$,(2003): Stress, leukocyte trafficking, and the augmentation of skin immune function. Ann. NY Acad. Sci. 992, 113 .

8-Rivier $C$ and Rivest $S$ (1991): Effect of stress on the activity of the hypothalamic-pituitary-gonadal axis: peripheral and central mechanisms. Biol Reprod ;45: 523-532. 9-Pacák $K$ and Palkovits M (2001): Stressor specificity of central neuroendocrine responses: implications for stress-related disorders. Endocr Rev ; 22:502-548.

10-Watkins LR, Milligan ED and Maier SF( 2003): Glial proinflammatory cytokines mediate exaggerated pain states: implications for clinical pain. Adv Exp Med Biol ;521 $: 1-21$.

11-Xie WR, Deng H and Li H ( 2006):Robust increase of cutaneous sensitivity, cytokine production and sympathetic sprouting in rats with localized inflammatory irritation of the spinal ganglia. Neuroscience ; 142:809-822.

12-Schafers M, Svensson $C I$ and Sommer C (2003): Tumor necrosis factor-alpha induces mechanical allodynia after spinal nerve ligation by activation of p38 MAPK in primary sensory neurons. J Neurosci ; 23:25172521.

14-Copray JC, Mantingh I and Brouwer $N$ (2001): Expression of interleukin-1 beta in rat dorsal root ganglia. J Neuroimmunol ;118:203211.

15-Watkins LR, Wiertelak EP and
Goehler LE (1994): Characterization of cytokine-induced hyperalgesia. Brain Res ; 654:15-26. 16-Sugo S, Minamino $N$ and Shoji H . (2012) :Interleukin-1, tumor necrosis factor and lipopolysaccharide additively stimulate production of adrenomedullin in vascular smooth muscle cells. Biochem Biophys Res Commun ; 207:25-32.

17-Ueda S, Nishio $K$ and Minamino N ( 2010): Increased plasma levels of adrenomedullin in patients with systemic inflammatory response syndrome. Am J Respir Crit Care Med ;160 :132-136.

18-Bajkova, O.V. (2008): CytoPhysiological indicator of the status of the reproductive organs of male rats after 7 days of immobilization stress \& 7 days of hypokinesia. Kosm Biol Aviakosm Med 22 (5): 55-59. Today ; 15:504-11

19-Chrousos GP . (2000): The role of stress and the hypothalamic-pituitaryadrenal axis in the pathogenesis of the metabolic syndrome: neuro-endocrine and target tissue-related causes. Int $\mathbf{J}$ Obes Relat Metab Disord ;24(Suppl. 2):S50-5.

20-Kanayama N, Khatun S, Belayet $H$, She $L$ and Terao $T$. (2009):Chronic immbolization stress to the soles induces hypertension in rats. Am J Hypertens ;12:1124-1129. 21-Marti $O$ and Armario A. (2012): Anterior pituitary response to stress: time-related changes and adaptation. Int $\mathbf{J}$ Dev Neurosci ;16:241-60.

22-Richard F, Faucon-biguet $\mathbf{N}$ and Labatut R (1999): Stress and workload of men and women in high-ranking positions. J. Occup. Health Psychol. 4, 142-151. 
23-Yan HQ, Banos MA and Herregodts P ( 1992 ): Expression of interleukin (IL)-1 beta, IL-6 and their respective receptors in the normal rat brain and after injury. Eur J Immunol ; 22: 2963-2971.

24-Sweitzer S, Martin D and Deleo JA (2001) :Intrathecal interleukin-1 receptor antagonist in combination with soluble tumor necrosis factor receptor exhibits an anti-allodynic action in a rat model of neuropathic pain.Neuroscience;103:529-539.

25-Rhind S, Castellani JW, Brenner IK. (2011): Intracellular monocyte and serum cytokine expression is modulated by exhausting exercise and immbolization stress. Am J Physiol Regul Integr Comp Physiol ; 281:6675.

26-Hangalapura BN, Kaiser MG, Poel JJ, Parmentier HK and Lamont SJ. (2011): Immobilization stress equally enhances in vivo proinflammatory cytokine gene expression in chicken lines divergently selected for antibody responses. Dev Comp Immunol ; 30:503-11. 27-Nukina H, Sudo N, Aiba Y, Oyama N, Koga $Y$ and Kubo C.(2001): Restraint stress elevates the plasma interleukin- 10 levels in germfree mice. J Neuroimmunol ;115:4652.

\section{8-Takaki A, Huang QH,} Somogyvari-Vigh A and Arimura A. (2013): Immobilization stress may increase plasma interleukin- 10 via central and peripheral catecholamines. Neuroimmunomodulat ion ;1:35-42. 29-Deliargyris EN, Raymond RJ, Theoharides TC, Boucher WS, Tate DA and Dehmer GJ.( 2011): Sites of interleukin-6 release in patients with acute coronary syndromes and in patients with congestive heart failure. Am J Cardiol ; 86:913-18. 30-Yuksel S, Yurekli M. (2012): The effect of adrenomedullin (AdM) on tyrosine hydroxylase (Th) enzyme activity and blood pressure in cold exposed rats. Endocr J , 553-9-1 4. 31-Yüksel S, Akbay A and Yürekli M (2002): Contribution of adrenomedullin to homeostatic response to cold stress in rat model. Pathophysiology ;8 :243-247. 33-Yuksel S. (2008): Altered adrenomedullin levels of the rats exposed to constant darkness and light stress. J Photochem Photobiol B Biol ; 91:20-3.

34-Isumi $Y$, Minamino $\mathbf{N}$ and Kubo A . (2008): Adrenomedullin stimulates interleukin-10 production in Swiss 3T3 cells. Biochem Biophys Res Commun ;244:325-313.

35-Ueda $S$, Nishio $K$ and Minamino N ( 2010):Increased plasma levels of adrenomedullin in patients with systemic inflammatory response syndrome. Am J Respir Crit Care Med ; 160:132-136.

36-Averina T.M ( 2000) :Morphofunctional characteristics of the immune adaptive capacities of the lymphoid tissue of the spleen in a growing body immobilization stress. Morphology.V congress of IAM, , v. $117, \quad 3, \quad$ p. $\quad 10$

37-Heijmans-Antonissen C, Wesseldijk F and Munnikes RJ (2006): Multiplex bead array assay for detection of 25 soluble cytokines in blister fluid of patients with complex regional pain syndrome type 1. Mediators Inflamm; 201:28-33. 38-Hideyuki N, Nobuyuki S, Yuhji A, Naomi $O$, Yasuhiro $K$ and 
Chiharu K. (2001): Restraint stress elevates the plasma interleukin-10 levels in germfree mice. J Neuroimmunol ;115:46-52. 39-Schoder H, Silverman DH and Campisi R . (2010): Effect of mental stress on myocardial blood flow and vasomotion in patients with coronary artery disease. J Nucl Med ;41:11-16.

40-Hirota H, Kiyama $H$ and Kishimoto T (1996):Accelerated Nerve Regeneration in Mice by upregulated expression of interleukin (IL) 10 and IL-6 receptor after trauma. J Exp Med ; 183:2627-2634. 41-Liu Y-L and Hui B, Chi S-M. (2007): The effect of compound nutrients on stress-induced changes in serum IL-2, IL-10 and TNF- $\alpha$ levels in rats. Cytokine ; 37:14-21. 


\section{تأثيرات ضغط عدم الحركة والادرينوموديولين علي معدل انترلوكين 10 في بعض انسجة الفئران}

احمد جادالله قسم الفسيولجي كلية الطب جامعة الازهر فرع اسيوط

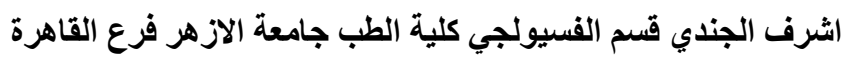

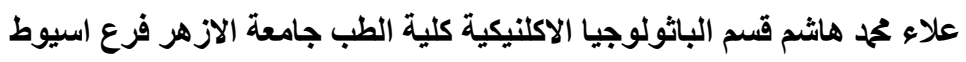

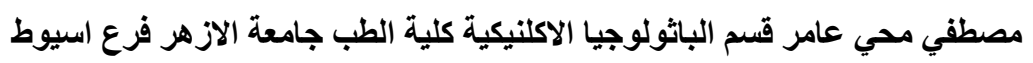

عمر صبري قسم الام معهد تيودور بلهارس للأبحاث بالقاهرة

خلفية البحث : من المعلوم ان ضغنط عدم الحركة يؤدي الي استثارة نشاط الجهاز

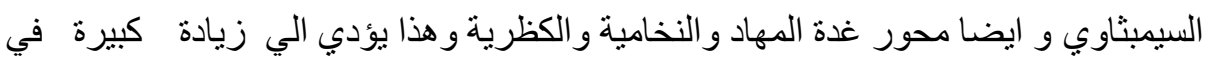

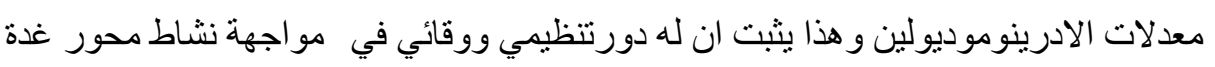

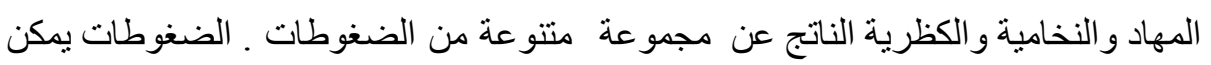

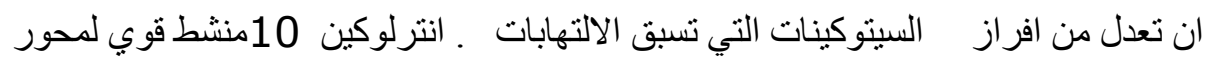

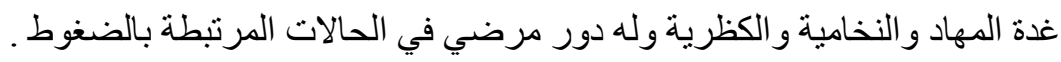

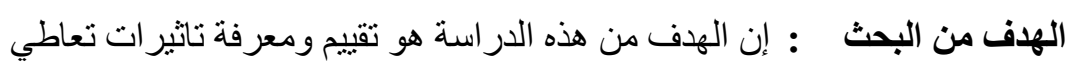

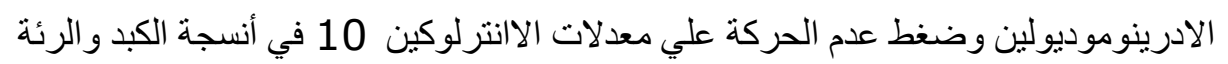
و المخ و القلب. طريقة البحث : : تمت الدراسة علي 24 فأرا أبيض ذكر ا عمر ها 8 شهور ووزنها يتراوح مابين 190-240 جم .وقد قسمت الفئران إلى اربع مجمو عات(كل مجموعة 6 فئران)

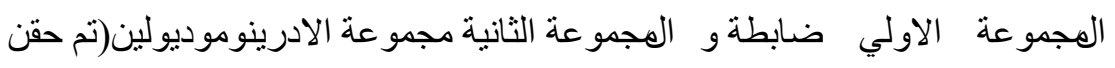

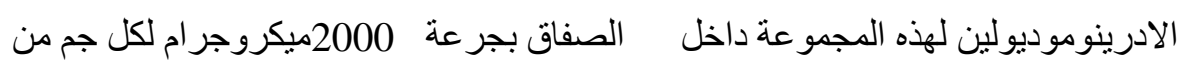

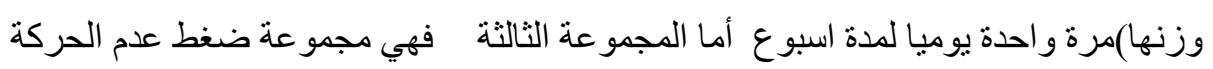

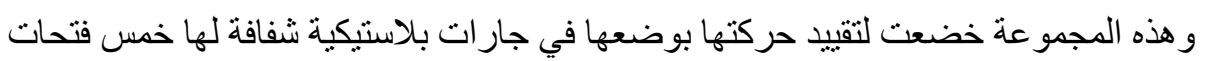

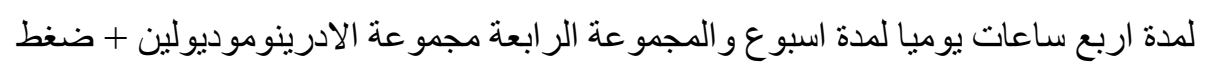

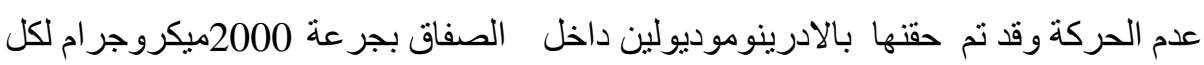


جم من وزنها مرة واحدة يوميا لمدة اسبوع ووفي نفس الوقت خضعت ايضا لتقييد حركتها

بوضعها في جار ات بلاستيكية شفافة لها خمس فتحات لمدة اربع ساعات يو ميا وفي نهاية

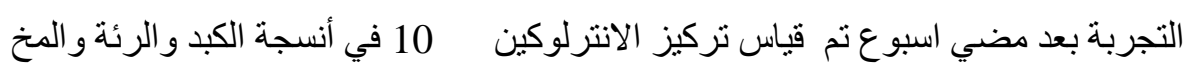
و القلب.

النتائج : لقد أظهرت نتيجة البحث إرتفاع معدل الانترلوكين 10 في كل الانسجة(القلب

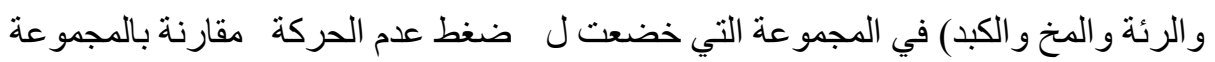

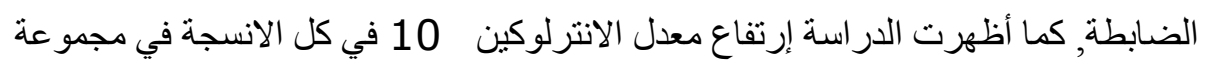
الادرينوموديولين مقارنة بالهمو عة الضابطة ,وقد لوحظ أيضا أن الارتفاع في الانترلوكين

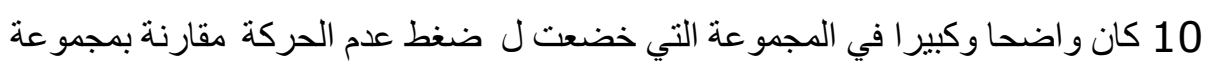

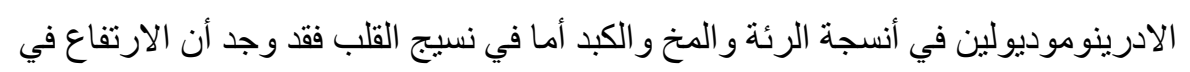

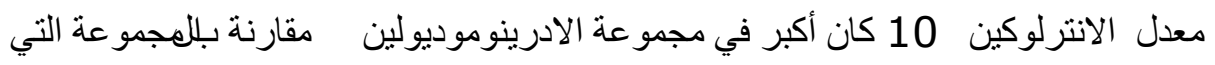
خضعت لضغط عدم الحركة. وقد أظهرت نتائج هذه الدراسة أيضا إنخفاض معدل الانترلوكين

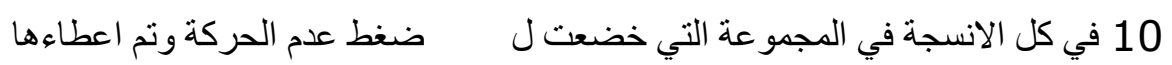
الادرينو موديولين (مجمو عة ضغط عدم الحركة+ الادرينوموديولين)مقارنة بالمجمو عة التي

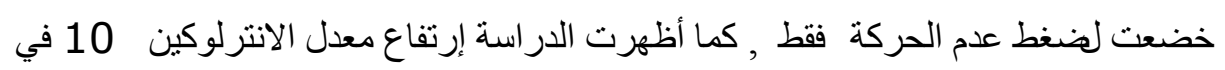
نسيجي الرئة و المخ و إنخفاض معدل الانترلوكين 10 في نسيجي القلب و الكبد في المجمو عة

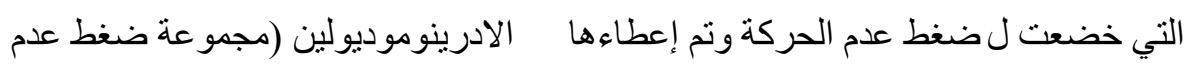

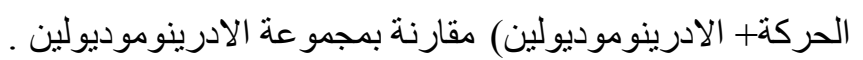
الاستنتاج: لقد أدي ضغط عدم الحركة الي إرتفاع معدل الانترلوكين 10 في أنسجة الفئر ان وكان للأدرينو موديولين دور منظم ووقائي لضغط عدم الحركة. 